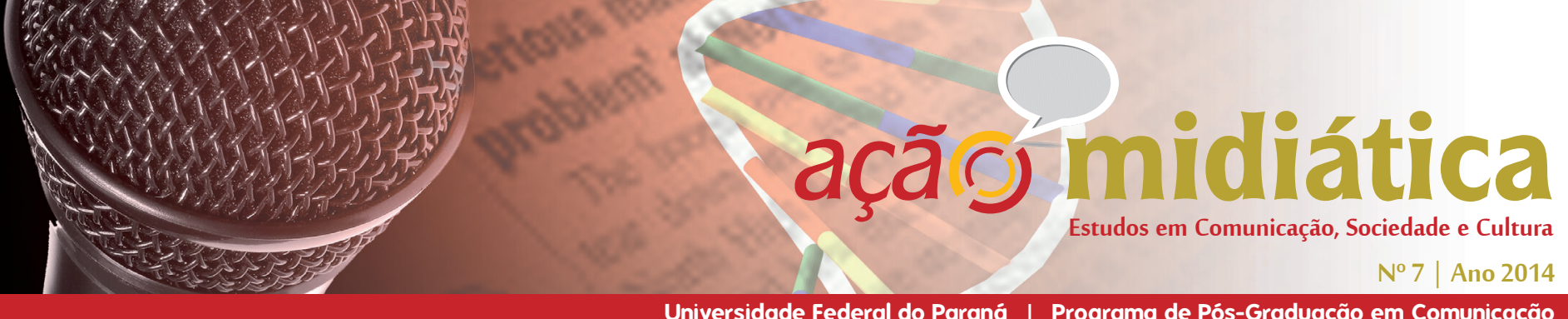

Universidade Federal do Paraná | Programa de Pós-Graduacãa em Comunicação

\title{
O Telejornalismo Estendido nas Redes Sociais: Participação ou Interação? ${ }^{1}$
}

\author{
The Extended Newscast on Social Networks: Interaction and Participation?
}

El Noticiero Extendido en las Redes Sociales: Interacción y Participación?

Paulo Eduardo Silva Lins CAJAZEIRA ${ }^{2}$

\begin{abstract}
Resumo
Os processos de convergência de mídias TV/Internet geram novas formas de participação da audiência no telejornalismo e simulam um sistema de interação dinâmico e aparentemente constante. Este estudo procura compreender as novas relações comunicacionais do telejornal, com o uso das Redes Sociais, na Internet. A presença quase onipresente da televisão na sociedade contemporânea tem apresentado uma alteração na produção e na recepção dos mass media. Na parte empírica da investigação, realizou-se um monitoramento das interações dos sujeitos (telejornal/público), nos perfis dos telejornais (fanpages) Edição da Manhã (SIC TV/Portugal) e Bom Dia Brasil (TV Globo/Brasil), na Rede Social Facebook, de 02 de setembro a 31 de dezembro de 2013, com o objetivo de verificar as novas formas de comunicação do telejornalismo estendido em multiplataformas digitais. As Teorias da Comunicação, a Semiótica e a Análise da Linguagem e do Conteúdo no ambiente virtual são tomadas como base para analisar as participações e as interações, por meio da interface das fanpages, na Internet.
\end{abstract}

Palavras-chave: Redes sociais; Fanpage; Participação; Audiência.

\begin{abstract}
The processes of media convergence TV/Internet create new forms of audience participation in TV journalism and simulate a system of dynamic and seemingly constant interaction. This study seeks to understand the new communication relations of the newscast, with the use of Social Networks on the Internet. The almost ubiquitous presence of television in contemporary society has brought a change in the production and reception of media. In the empirical part of the research carried out a monitoring of the interactions of individuals (newscast/public), the profiles of TV news (fanpages), Edição da Manhã (SIC TV/ Portugal) and Bom Dia Brasil (TV Globo/Brasil) in Social Network Facebook 02 September to 30 December 2013, with the objective of verifying the new forms of communication in extended digital multiplatform television news. Theories of Communication and Semiotics Analysis of Language and Content in the virtual environment are taken as a basis to analyze the holdings

1 Trabalho apresentado à sétima edição da Revista Ação Midiática - Estudos em Comunicação, Sociedade e Cultura, publicação ligada ao Programa de Pós-Graduação em Comunicação, da Universidade Federal do Paraná.

2 Professor Efetivo do Curso de Comunicação e Jornalismo da Universidade Federal do Cariri, Ceará, Brasil. Pesquisa Pós-Doutoral no Laboratório de Comunicação e Conteúdos Online da Universidade da Beira Interior, Portugal, sob a supervisão do Prof. Dr. António Fidalgo. Jornalista e Doutor em Comunicação e Semiótica pela Pontifícia Universidade Católica de São Paulo. Bolsista de Pesquisa Pós-Doutoral no Exterior da Fundação Capes sob o número de processo: 3264/13-0. Líder do Grupo de Pesquisas: Centro de Estudos e Pesquisa em Jornalismo (CEPEJor/UFC/CNPq). E-mail: ecajazeira@, $\underline{\text { hotmail.com }}$
\end{abstract}


Esse questionamento teórico dará base para a investigação, que se circunscreve na observação dos processos e das práticas que direcionam a análise dos modos de interação do telejornal/público e dos vínculos constituídos na sociedade em constante midiatização. Este será o cerne da questão que permeará toda a investigação em torno dessa intercomunicação circular, ampliada pela TV e mediada pela Tecnologia/Internet. Um sistema convergente que redireciona a audiência aos novos espaços, reordena e molda as relações interpessoais com o uso das inovações tecnológicas.

Com a ampliação e a desterritorialização do espaço televisivo e a sua inserção no mundo virtual, as conversas e os assuntos expandiram-se para outros lugares e tempos com dinâmicas diferentes de funcionamento. O público/usuário do telejornalismo incorpora-se aos novos formatos nas Redes Sociais e na $W e b$, ao querer participar dos espaços da audiência desenvolvidos pelas corporações de informação e comunicação. As fanpages tornaram-se um desses novos espaços de legitimação, para o qual o telejornalismo migrou, a fim de inserir-se no ambiente de conversação do público, usuário desses ambientes de socialização. O que podemos compreender inicialmente é que esses espaços de comunicabilidade trazem uma legitimação dos discursos midiáticos no espaço virtual e ampliam as possibilidades de comunicação entre os sujeitos.

O destinador/televisão mostra-se interessado em persuadir o destinatário/público, isto é, fazê-lo crer no simulacro de aproximação do telejornal instalado no ambiente da fanpage. A compreensão do saber fazer da televisão está diretamente ligada ao fazer crer do público. Isso significa imaginar que os efeitos causados pela mídia estão ligados ao que o destinatário do discurso faz com o conteúdo televisivo disponibilizado em multiplataformas. Demandas que põem em jogo o contínuo fazer-se e desfazer-se de identidades coletivas e modos como se alimentam e projetam as representações sociais no meio de comunicação.

Nesse sentido, percebe-se a relação entre o público e o telejornal no Facebook como uma quase interação social aos moldes conceituais de John Thompson (1998). Essa potencial sensação de comunicação efetiva (e não apenas consumo de informação) com os profissionais de televisão "representados" na Rede Social é exatamente o que caracteriza a "quase interação mediada" na Rede Social. Há o espaço discursivo ilimitado, mas a troca comunicacional praticamente não há entre o seguidor e a administração da fanpage. O telejornal utiliza-se do processo circular do agir comunicativo definido por Jürgen Habermas (2003), no qual o ator social seria as duas coisas ao mesmo tempo: o iniciador, que domina as situações por meio de ações imputáveis, e, ao mesmo tempo, o produto das tradições, dos grupos solidários aos quais pertence e dos processos de socialização nos quais se cria a interação. O valor da argumentação, nesse caso, é dado pelo contexto em função do que cada interlocutor quer compreender para ter o resultado desejado, ou seja, 


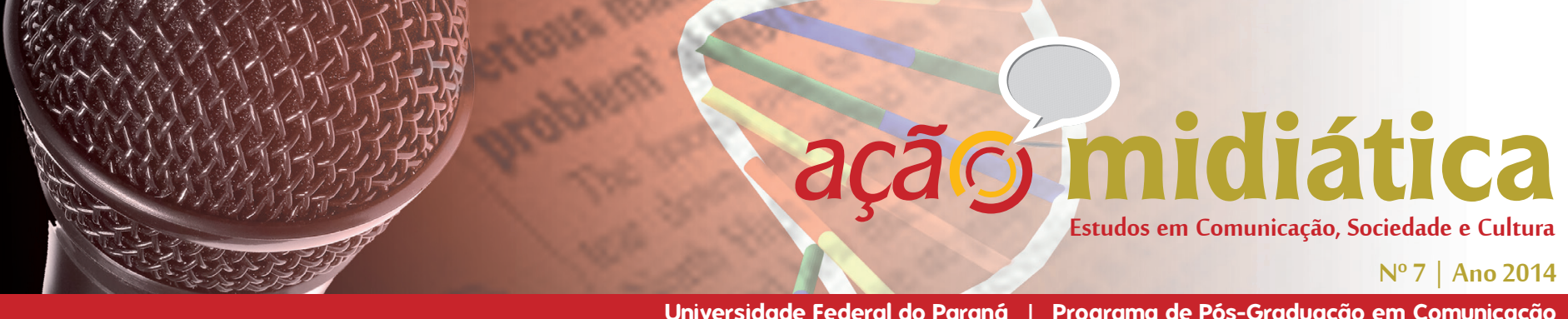

muda, tudo já foi transformado.

No caso das interfaces virtuais, a comunicação entre os seus interagentes já havia sido transformada com o surgimento das relações mediadas pelo computador. "O corpo tornou-se um reflexo do seu entorno, que processa as informações e depois as expressa ao mundo. Trata-se de um corpo-veículo-de-comunicação, um corpo recipiente, no qual se processa e depois se devolve ao local de origem. A informação não é expressa e depois processada, pois a informação torna-se corpo" (KATZ, 2008, p. 3). O ambiente no qual a mensagem é emitida não é estático, mas contextualizado com o fluxo de informações que interagem e comandam as suas ações. A comunicação nesse meio desenvolve-se com formas próprias de linguagem, mas sem perder as características que a constituem.

\section{O estudo de caso luso-brasileiro}

Neste estudo, buscamos desenvolver uma análise comparativa da realidade de dois telejornais que possuem páginas ativas na Rede Social Facebook: Bom Dia Brasil (TV Globo, Brasil) e Edição da Manhã (SIC Notícias, Portugal). A escolha pelo estudo comparativo entre Brasil e Portugal explora a relação cultural local do público do telejornal, como o hábito profissional dos jornalistas de interagirem com a sua audiência por meio das Redes Sociais Digitais. No ano de 2008, enquanto o Brasil assistia ao crescimento de utilizadores da Rede Social Orkut, do outro lado do Atlântico aumentava o número de adeptos portugueses ao Facebook. Percebe-se, à primeira vista, uma diferença temporal nos hábitos português e brasileiro com relação ao uso de determinadas plataformas de Redes Sociais Digitais.

A SIC TV, em 14/09/2009, criou a sua fanpage do telejornal Edição da Manhã, enquanto a TV Globo, apenas em 04/10/2011, ou seja, quase dois anos após a experiência portuguesa, entrou com a página do Bom Dia Brasil no Facebook. Até o ano de 2014, a TV Globo subutilizava-se da potencialidade da plataforma no compartilhamento de vídeos, reportagens, fóruns e enquetes, limitando-se a inserir a imagem do apresentador do telejornal acompanhada de texto-legenda que solicitava ao seguidor da página ligar a sua TV, quando o jornal entrava no ar. Ao contrário da fanpage portuguesa que explorava, desde o seu início, as diferentes formas de comunicabilidade no ambiente midiático, como o compartilhamento de vídeos de reportagens mostradas na edição diária do telejornal, além de promover campanhas sociais, fóruns e outras discussões, com o intuito de aproximar-se do interagente, na Internet. Essas constatações iniciais de atuações diferentes, no âmbito do telejornalismo, motivaram-nos a observar com maior acuidade o desempenho dos sujeitos: telejornal, fanpage e utilizador na Rede Social Facebook.

No momento em que a televisão enfrenta o desafio de lidar com a desterritorialização 


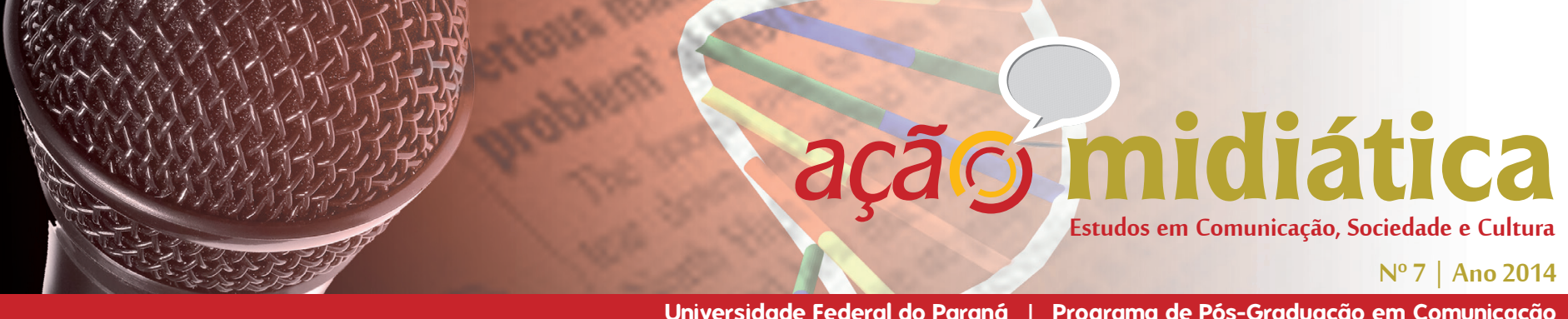

da audiência em multiplataformas, e ao mesmo tempo manter a sua identidade, buscamos responder se existe diferença significativa do conteúdo do jornalismo televisivo convergido nas Redes Sociais praticado em países de culturas sociais diferentes ou se o hábito profissional em realidades distintas sobrepuja essa diferença. O instrumental metodológico contou com: o monitoramento das interações na fanpage dos telejornais no período de 02 de setembro a 31 de dezembro de 2013, o mapeamento das características dos interagentes e os interesses das notícias pelo público. A investigação se concentrou em compreender o cenário e as inter-relações dos fatores envolvidos na prática do telejornalismo.

Os resultados da pesquisa revelaram, entre outros pontos, que a maioria dos profissionais de TV não está preparada para interagir com a prática do jornalismo na Rede Social, optando ainda por não explorar as potencialidades da plataforma digital, no que concerne ao distribuir e circular do material noticioso e ao explorar novas possibilidades de interação e de fidelização da audiência no ambiente midiático. O estudo apontou ainda que a relação entre os sujeitos se dá por meio de representações simbólicas das imagens dos interagentes: apresentadores dos telejornais e seguidores da fanpage, além dos interesses do público por reportagens com temáticas locais alinhadas ao valor-notícia de proximidade.

\section{Edição da Manhã}

O telejornal Edição da Manhã é um noticiário televisivo português da SIC TV e do canal fechado da SIC Notícias, exibido de segunda a sexta-feira, das 07h00 às $10 \mathrm{~h} 00$. É apresentado pelo jornalista e editor João Moleira. O tempo de exibição na SIC TV é, em média, das $07 \mathrm{~h} 00$ às $08 \mathrm{~h} 40$, e na SIC Notícias (canal a cabo) é das $07 \mathrm{~h} 00$ às $10 \mathrm{~h} 00$. A Edição da Manhã foi o primeiro momento da emissão da SIC Notícias, em janeiro de 2001, o primeiro canal de notícias (All news ${ }^{3}$ ) em português. A linha editorial engloba economia, política, geral, esporte, cultura, factual, análises de comentaristas e entrevistas. Há, em cada edição, a escolha de um tema principal em torno do qual se estrutura o telejornal. Os convidados em estúdio estão sempre, de algum modo, relacionados a esse tema. $\mathrm{Na}$ Edição da Manhã, às notícias somam-se as primeiras páginas dos jornais, o trânsito em Lisboa e no Porto, a meteorologia, os mercados financeiros e o Jornal de Economia (em colaboração e com a participação de editores do semanário Expresso e da revista Exame). Alguns jornalistas desses dois veículos são convidados a participar do jornal ao vivo. O público-alvo corresponde às classes $\mathrm{A}, \mathrm{A}+, \mathrm{B}, \mathrm{B}+\mathrm{e} \mathrm{C}$. Perfil no Facebook: 30.000 likes.

3 Termo da língua inglesa que significa "totalmente notícias" é usado para designar uma emissora, seja de rádio, seja de televisão, cuja programação é composta apenas de notícias ou reportagens, ou seja, de cunho jornalístico. 


\section{BOM DIA BRASIL}

SETEMBRO - 2013

\begin{tabular}{lccccc} 
Bom Dia Brasil (TV GLOBO) & 1. $^{\text {a }}$ semana & 2. $^{\text {a }}$ semana & 3. $^{\text {a }}$ semana & 4. $^{\text {a }}$ semana & TOTAL \\
\hline Likes & 5.320 & 4.146 & - & 23.516 & 32.982 \\
Comentários & 385 & 335 & - & 1.761 & 2.481 \\
Compartilhamentos & 338 & 129 & - & 836 & 1.303
\end{tabular}

Total: likes (32.982), comentários (2.481) e compartilhamentos (1.303). Total de interações no mês: (36.766)

OUTUBRO - 2013

\begin{tabular}{lccccc} 
Bom Dia Brasil & $\mathbf{1 .}^{\mathbf{a}}$ semana & 2. $^{\mathbf{a}}$ semana & 3. $^{\mathbf{a}}$ semana & $\mathbf{4 .}^{\mathbf{a}}$ semana & $\mathbf{5 .}^{\mathbf{a}}$ semana \\
\hline Likes & 20.938 & 35.703 & 11.113 & 25.595 & 21.558 \\
Comentários & 1.394 & 2.278 & 327 & - & 3.999 \\
Compartilhamentos & 625 & 1.032 & 119 & - & 1.303
\end{tabular}

Total: likes (114.607), comentários (7.224) e compartilhamentos (3.290). Total de interações no mês: (125.121)

NOVEMBRO - 2013

\begin{tabular}{lccccc} 
Bom Dia Brasil & 1. $^{\mathbf{a}}$ semana & 2. $^{\text {a }}$ semana & 3. $^{\text {a }}$ semana & 4. $^{\text {a }}$ semana & 5. $^{\text {a }}$ semana \\
\hline Likes & 5.802 & 32.183 & 24.787 & 30.695 & 29.760 \\
Comentários & 348 & 1.837 & 1.298 & 1.643 & 1.647 \\
Compartilhamentos & 225 & 853 & 638 & 789 & 807
\end{tabular}

Total: likes (92.532), comentários (6.773) e compartilhamentos (3.357). Total de interações no mês: (102.662)

\section{DEZEMBRO - 2013}

\begin{tabular}{lccccc} 
Bom Dia Brasil & 1. $^{\text {a }}$ semana & 2. $^{\text {a }}$ semana & 3. $^{\text {a }}$ semana & 4. $^{\text {a }}$ semana & 5. $^{\text {a }}$ semana \\
\hline Likes & 28.688 & 26.939 & 24.674 & 23.754 & 16.541 \\
Comentários & 1.820 & 1.400 & 1.264 & 1.090 & 898 \\
Compartilhamentos & 479 & 417 & 387 & 350 & 309
\end{tabular}

Total: likes (120.596), comentários (5.574) e compartilhamentos (1.942). Total de interações no mês: (128.112) 


\section{EDIÇÃO DA MANHÃ}

SETEMBRO - 2013

$\begin{array}{lcccrc}\text { Edição da Manhã (SICTV) } & \text { 1. }^{\text {a }} \text { semana } & \mathbf{2 .}^{\text {a }} \text { semana } & \text { 3. }^{\text {a }} \text { semana } & \text { 4. }^{\text {a }} \text { semana } & \text { TOTAL } \\ \text { Likes } & 47 & 26 & - & 88 & 161 \\ \text { Comentários } & 09 & 13 & - & 16 & 38 \\ \text { Compartilhamentos } & 0 & 0 & - & 0 & 0\end{array}$

Total: likes (161), comentários (38) e compartilhamentos (0). Total de interações no mês: (199)

OUTUBRO - 2013

$\begin{array}{lccccc}\text { Edição da Manhã (SICTV) } & \text { 1. }^{\text {a }} \text { semana } & \mathbf{2 .}^{\text {a }} \text { semana } & \text { 3. }^{\text {a }} \text { semana } & \text { 4. }^{\text {a }} \text { semana } & \text { 5. }^{\text {a }} \text { semana } \\ \text { Likes } & 115 & 128 & 160 & 108 & 124 \\ \text { Comentários } & 12 & 22 & 29 & 18 & 30 \\ \text { Compartilhamentos } & 0 & 0 & 0 & 0 & 1\end{array}$

Total: likes (635), comentários (111) e compartilhamentos (1). Total de interações no mês: (647)

NOVEMBRO - 2013

\begin{tabular}{lccccc} 
Edição da Manhã (SICTV) & $\mathbf{1 .}^{\text {a }}$ semana & 2. $^{\text {a }}$ semana & 3. $^{\text {a }}$ semana & 4. $^{\text {a }}$ semana & TOTAL \\
\hline Likes & 184 & 142 & 127 & 130 & 583 \\
Comentários & 29 & 32 & 7 & 27 & 95 \\
Compartilhamentos & 06 & 03 & 17 & 01 & 27
\end{tabular}

Total: likes (583), comentários (95) e compartilhamentos (27). Total de interações no mês: (705)

\section{DEZEMBRO - 2013}

$\begin{array}{lccccc}\text { Edição da Manhã (SICTV) } & \text { 1. }^{\mathbf{a}} \text { semana } & \text { 2. }^{\text {a }} \text { semana } & \text { 3. }^{\text {a }} \text { semana } & \text { 4. }^{\text {a }} \text { semana } & \text { TOTAL } \\ \text { Likes } & 02 & 215 & 210 & 220 & 647 \\ \text { Comentários } & 0 & 21 & 25 & 17 & 63 \\ \text { Compartilhamentos } & 0 & 0 & 0 & 02 & 02\end{array}$

Total: likes (647), comentários (63) e compartilhamentos (04). Total de interações no mês: (712)

Fonte: Monitoramento das fanpages dos telejornais Edição da Manhã e Bom Dia Brasil no Facebook (2013). 


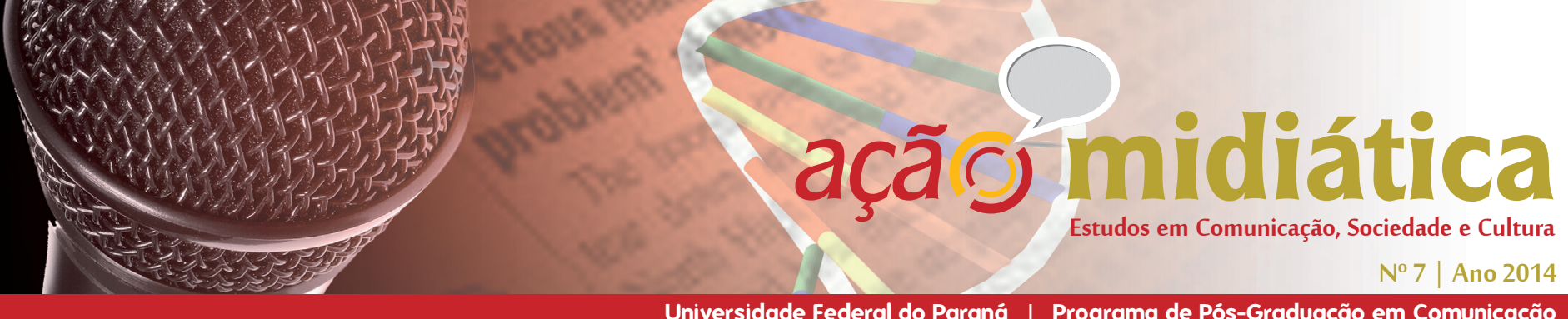

Nos horários em que os telejornais estão fora do ar, o número de likes, comentários, shares na fanpage é menor. Os posts com maior participação registrada são aqueles que trazem uma pergunta, uma enquete ou um pedido de opinião do usuário, o que reforça o caráter reativo das audiências: não se produz conteúdo, apenas reage-se ao que foi publicado pelo telejornal. A maior parte dos telespectadores (fãs) limita-se a clicar no like. Pode-se dizer que o número de pessoas a marcar like é maior que o de pessoas que publicam comentários nos posts. É comum um fã comentar mais de uma vez o mesmo post.

Contudo, o que se verifica é que não há interação interna entre o grupo de fãs no ambiente virtual, apenas emissões individuais de opinião quanto aos conteúdos publicados pelo telejornal, no melhor estilo fanpost $t^{5}$. Em nenhum momento, dentro do período analisado, houve resposta aos telespectadores por parte do telejornal quanto aos seus comentários. Isso pode se dever ao fato de que o público ativo utiliza pouco esse canal de interação para sugestões de pautas, informações sobre alguma reportagem ou entrevistados, resumindo-se a concordar com o que alguns usuários escrevem nos posts. Esse ato desencadeia uma unilateralidade comunicacional no ambiente midiático da Rede Social, por parte de enunciadores e seguidores da fanpage.

\section{Como os telejornais desenvolvem a interação com o telespectador nas "fanpages"}

Nos dois telejornais, verificou-se que o avatar ${ }^{6}$ do apresentador assume o discurso como representante do telejornal. O público o reconhece como tal e interage com a imagem como se estivesse a conversar, mediado pelo computador, com o apresentador do programa. A imagem apresenta-se como um sujeito, que se manifesta no ato individual de utilização da língua pelo falante, em um dado contexto comunicativo. O contexto é a situação comunicativa concreta em que o texto é produzido, envolvendo o enquadramento concreto em que a enunciação se desenvolve entre emissor e receptor da mensagem (MOURA, 2009). Com isso, discute-se, no âmbito enunciativo, essa relação comunicacional entre o ídolo (telejornal/apresentadores) e o fã (público/usuário da "fanpage”) do telejornal na Rede Social.

O pesquisador Roland Barthes (1957), em sua obra "Mitologias", define a figura do "mito", que denominamos neste estudo de "ídolo", como um sistema de comunicação, uma mensagem. Por aí se vê que o mito não pode ser de modo nenhum um objeto, um conceito ou uma ideia; é um modo de significação, uma forma. Compreendemos que o mito é uma fala, um

5 Conforme se verificou na investigação, o estilo fanpost diz respeito à forma mais usual e simples de interação nas Redes Sociais Digitais. Geralmente no formato de likes e comentários pouco aprofundados.

6 A palavra avatar se tornou popular entre os meios de comunicação e informática devido às figuras que são criadas à imagem e semelhança do usuário, permitindo sua "personalização" no interior das máquinas e telas de computador. Tal criação assemelha-se a um avatar por ser uma transcendência da imagem da pessoa, que ganha um corpo virtual, desde os anos 80 , quando o nome foi usado pela primeira vez em um jogo de computador. No caso das fanpages, os usuários (fãs) interagem com o seu ídolo por meio da imagem ou avatar. 


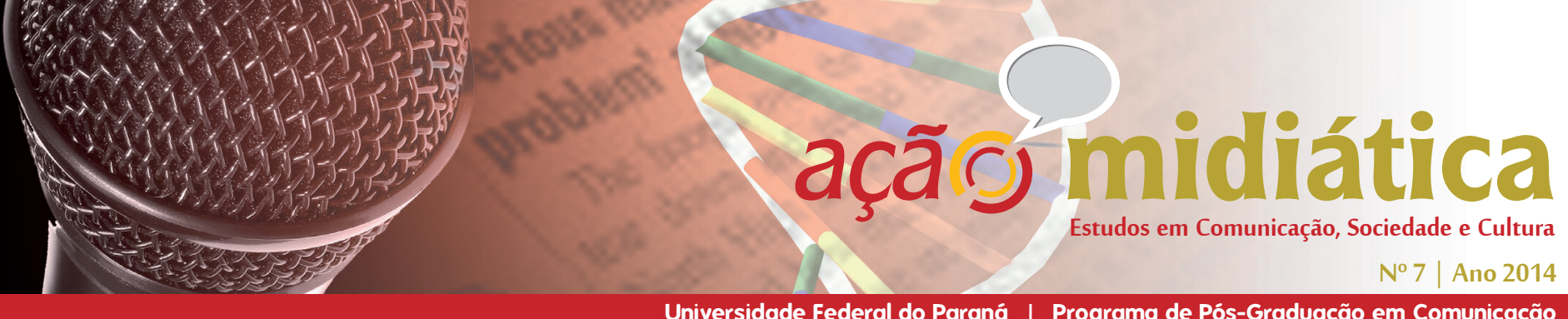

Universidade Federal do Paraná | Programa de Pós-Graduação em Comunicação

nesse novo espaço midiático de articulação da esfera pública e social. A representação das imagens que representam os "avatares" dos apresentadores Chico Pinheiro (Bom Dia Brasil) e João Moleira (Edição da Manhã) interage com os fãs dos jornais nas Redes Sociais. Quando os apresentadores, na versão de seus avatares, dizem “Bom Dia, quem está aí conosco?”, “O Edição da Manhã está no ar, quem está aí do outro lado?" ou "Ligue a sua TV agora. O Bom Dia está no ar", essas ordenações se destinam a chamar a audiência, na plataforma digital, a acompanhá-los na TV.

Marialva Barbosa (2007, p. 6) afirma que "há que se considerar a dependência desses regimes de oralidade. Nas cenas da TV, existe sempre a reprodução das maneiras como o público estabelece as suas falas no cotidiano". As palavras são construídas em um contexto de locução, no qual a imagem de quem fala, a sua entonação e seu gestual são fundamentais para a compreensão do dito e do não dito. A seguir, temos, de segunda a sexta-feira, a saudação do apresentador do Bom Dia Brasil, Chico Pinheiro, com alguns dos seus bordões que se repetem na fanpage. A representação imagética do apresentador reproduz, discursivamente, o mesmo diálogo quando saúda o público no início da edição, no estúdio de TV.

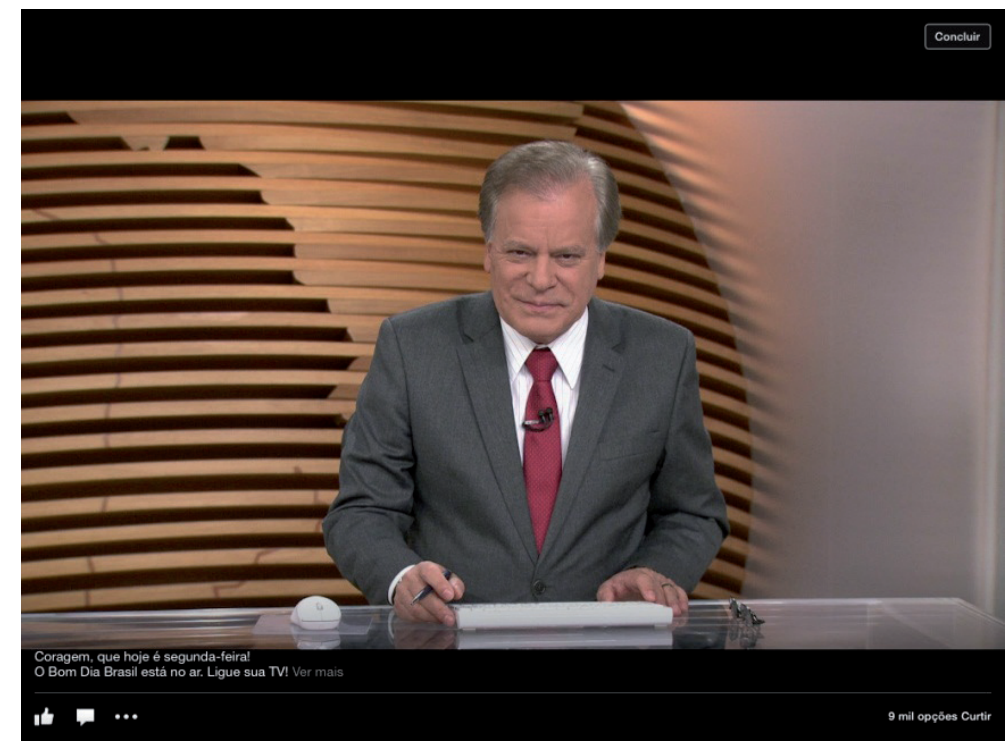

Figura 1 - "Coragem, que hoje é segunda-feira!" (Bom Dia Brasil) Fonte: www.facebook.com $\backslash$ bomdiabrasil 


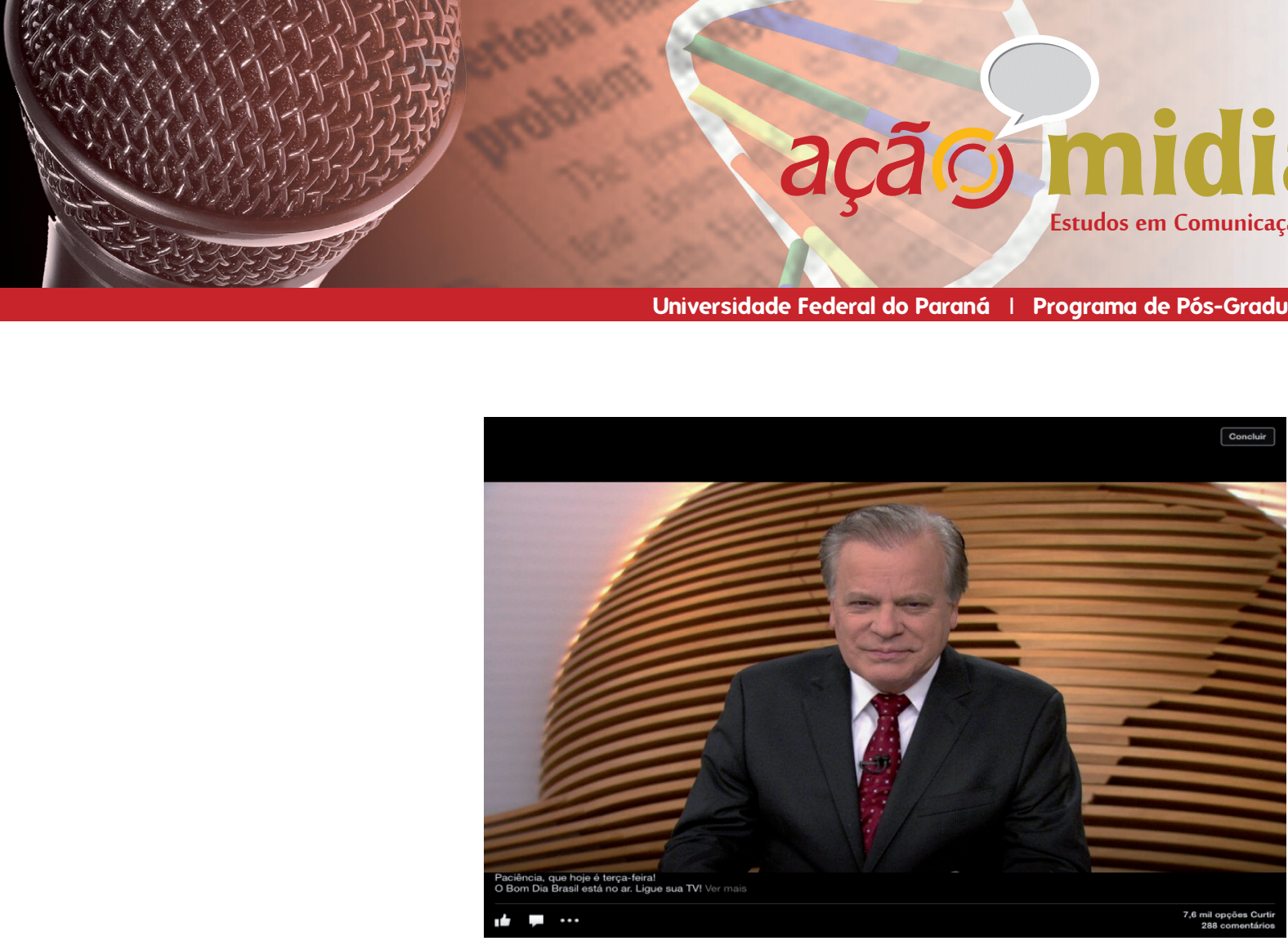

Figura 2 - "Paciência, que hoje é terça-feira!" (Bom Dia Brasil) Fonte: www.facebook.comlbomdiabrasil

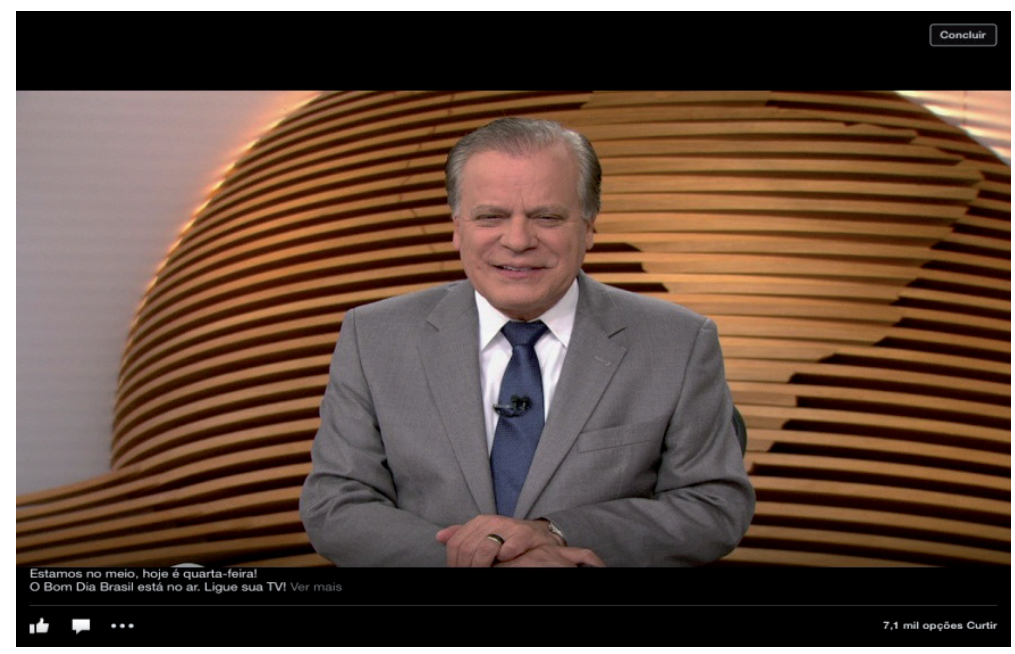

Figura 3 - "Estamos no meio, hoje é quarta-feira!" (Bom Dia Brasil) Fonte: www.facebook.comlbomdiabrasil 
Walter Benjamin (2012), a linguagem significa o princípio orientado para a comunicação de conteúdos intelectuais, nos referidos domínios: na técnica, na arte, na justiça ou na religião. Em uma palavra: toda e qualquer comunicação de conteúdos é linguagem, sendo a comunicação por meio da palavra apenas um caso particular, subjacente a conteúdos humanos ou que neles se baseia (justiça, poesia etc.).

Compreendemos, baseados nessa afirmação, que a essência linguística da comunicação do apresentador é a sua linguagem, a forma como se comunica, seja na fanpage ou ao vivo no estúdio de TV. As palavras em tons coloquiais utilizadas no início de cada edição do telejornal e reproduzidas na fanpage - "Graças a Deus é sexta-feira!; Coragem, que hoje é segunda-feira!; Calma, que hoje é quinta-feira!" - são exemplos que designam a intencionalidade do jornalista em aproximar-se do público, por meio de expressões próprias da oralidade. Essa característica da linguagem estabelece uma conexão absoluta nos espaços televisivos, caracterizada como atos de fala, uma vez que, ao serem enunciadas as frases, indicam o tipo de ato determinado pela forma geral da frase, pela entonação e seu contexto situacional.

Como explica José de Almeida Moura (2009), ao enunciar uma frase completa, o locutor cumpre três atos de fala simultâneos, porque dizer é já dizer: 1) um ato locutório, que corresponde ao fato de falar, pois o locutor articula e combina os elementos mínimos da frase, envolvendo a componente fonológica e morfológica mais a estrutura sintático-semântica da frase; 2) um ato ilocutório, pois o locutor, com a enunciação da frase, tem intenção de agir sobre o destinatário, comunicando-lhe uma informação, expondo ou defendendo um ponto de vista, confirmando ou refutando uma asserção, fazendo-lhe um pedido, questionando-o, dando-lhe uma ordem ou uma solicitação; 3) um ou mais atos de perlocutórios, uma vez que, de acordo com a situação enunciativa e para além do que é dito, o enunciado acaba por ter outros efeitos no destinatário, desencadeando nele emoções, levando-o a aderir ou a opor-se, incitando-o ou retirando-lhe, esclarecendo-lhe o ânimo.

Os valores semânticos e pragmáticos da entonação (persuasão, ordem, indiferenças, cólera ou ironia) são gestos por meio dos quais o apresentador do programa jornalístico se articula e exprime as informações. Por exemplo, o tom com que pronuncia as expressões "coragem", "paciência", "estamos no meio", "calma" e "graças a Deus”, pode traduzir desejo, admiração, espanto ou aprovação. O conhecimento dos valores da entonação pelo destinatário desenvolve as capacidades de compreensão, interpretação e expressão oral. O enunciado oral só é perfeitamente compreendido pelo interlocutor no ambiente midiático, quando se considera a informação veiculada pela entonação utilizada pelo enunciador (MOURA, 2009). As palavras resultantes da entonação sugerem uma ação ou o resultado da própria ação que o destinador do discurso procura fazer sobre o seu destinatário. 


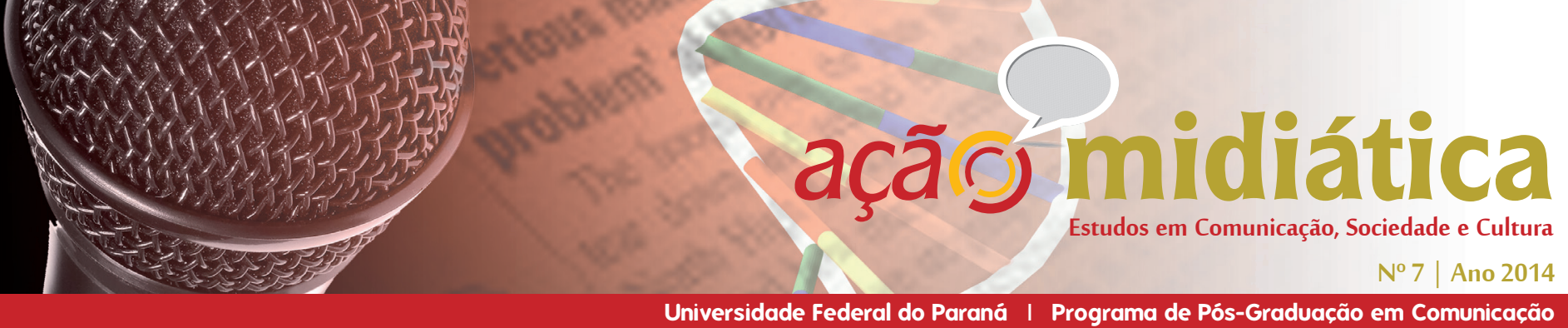

THOMPSON, J. (1998). Mídia e Modernidade: Uma teoria social da mídia. Petrópolis, RJ: Vozes.

ZUMTHOR, P. (2007) In BARBOSA, M. Televisão, Narrativa e Restos do Passado. Disponível em: http://www.compos.org.br/seer/index.php/e-compos/article/view/138. Acesso em: $18 / 11 / 2013$.

\section{Referências eletrônicas}

www.facebook.com/BomDiaBrasil

www.facebook.com/edicaodamanha

www.facebook.com

http://sicnoticias.sapo.pt

http://g1.globo.com 